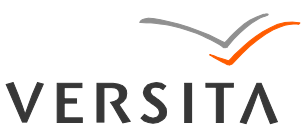

GEOCHRONOMETRIA 40(4) 2013: 283-293

DOI 10.2478/s13386-013-0120-y

Available online at

www.springerlink.com

\title{
THE EFFECT OF FLUVIAL ENVIRONMENTS ON SEDIMENT BLEACHING AND HOLOCENE LUMINESCENCE AGES - A CASE STUDY FROM THE GERMAN ALPINE FORELAND
}

\author{
PATRICK SCHIELEIN ${ }^{1,2}$ and JOHANNA LOMAX ${ }^{3,4}$ \\ ${ }^{1}$ Department of Geography, University of Bamberg, Am Kranen 1, D-96045 Bamberg, Germany \\ ${ }^{2}$ Department of Geography, Nara Women's University, Kita-Uoya Nishimachi, Nara 630-8506, Japan \\ ${ }^{3}$ Department of Geography, Justus-Liebig-University Giessen, Senckenbergstr. 1, 35390 Giessen, Germany \\ ${ }^{4}$ Institute of Applied Geology, University of Natural Resources and Life Sciences, Peter Jordan-Str. 70, A-1190 Vienna, Austria.
}

Received 31 January $2013 \quad$ Accepted 28 June 2013

\begin{abstract}
This study investigates the potential of luminescence to date deposits from different fluvial sedimentary environments; namely point bar deposits, sandy and silty channel fills and floodplain sediments. Samples were taken from Holocene $(<5 \mathrm{ka})$ terraces of the Lech and Danube rivers, for which independent age constraint is available through ${ }^{14} \mathrm{C}$ ages, archaeological data and historical maps. OSL-ages were obtained using small aliquots of coarse grain quartz for the majority of samples. Two further samples were dated by the IRSL-signals of polymineral fine grain extracts, as no sufficient number of coarse grains could be extracted from these sediments. In order to detect and account for incomplete bleaching, we used the decision process suggested by Bailey and Arnold [Statistical modelling of single grain quartz $\mathrm{D}_{\mathrm{e}}$ distributions and an assessment of procedures for estimating burial dose. Quaternary Science Reviews 25, 2475-2502, 2006]. Although their model was designed for single grains of quartz, our study shows that it is also applicable to multiple grains of quartz, provided that a low number of luminescent grains is present on one aliquot. Luminescence ages of point bar deposits and a sandy channel fill correspond most closely to the independent age control. In the floodplain, sand-striped floodplain channel deposits were incompletely bleached to a moderate degree, yielding ages with acceptable overestimations, while fine-grained floodplain deposits were worst bleached. One crevasse splay deposit was so severely incompletely bleached that none of the age models was able to yield accurate ages.
\end{abstract}

Keywords: luminescence dating, quartz multi-grain, independent age control, fluvial sedimentary environments, incomplete bleaching, Northern Alpine Foreland.

\section{INTRODUCTION}

The timing of fluvial deposition can be determined by means of luminescence dating, (for recent reviews, see Rittenour, 2008; Fuchs and Owen, 2008; Thrasher et al., 2009a). However there are different reasons why dating

Corresponding author: P. Schielein

e-mail: patrick.schielein@uni-bamberg.de of these deposits may be problematic. Resetting of the luminescence signal may be incomplete due to the waterlain nature of these sediments, causing age overestimation if not accounted for. This problem has shown to be particularly relevant for young sediments (e.g. Jain et al., 2004; Rodnight et al., 2006; Fiebig et al., 2009). Incomplete bleaching results in scattered and positively skewed equivalent dose $\left(\mathrm{D}_{\mathrm{e}}\right)$ distributions (e.g. Olley et al., 
1998). Further, low quartz signal intensities have been reported from many mountainous areas (e.g. Rhodes and Pownall, 1994; Preusser et al., 2006; Klasen et al., 2006; Lukas et al., 2007; Steffen et al., 2009). Most likely this problem is linked to the low number of sedimentation cycles experienced from source to depositional area (Lukas et al., 2007; Pietsch et al., 2008).

The aim of this study is to test quartz luminescence dating on known age Holocene fluvial deposits of the Lech and Danube rivers. Independent age control in the current study is available through ${ }^{14} \mathrm{C}$ ages, archaeological data and stratigraphical classifications (Schielein, 2012). The samples were taken from different fluvial sedimentary environments, namely bar deposits, channel fills and floodplain deposits. The luminescence ages are based on small single aliquot dating of quartz and will be used to test whether sedimentological properties affect the accuracy and precision of luminescence dating results. The mode of $D_{e}$ calculation follows the decision process of Bailey and Arnold (2006). The decision process was originally designed to be used for single grains, and so the applicability of this process to multiple grain replicas of quartz was also tested. Further two samples were dated by their polymineral fine grain fraction using IR-stimulation, as there was not enough material for quartz coarse grain extraction. This aliquot size does not allow $\mathrm{D}_{\mathrm{e}}$ distribution analyses, thus the accuracy of IRSL ages of these two samples is based only on the comparison with the independent age control.

\section{STUDY AREA}

\section{Geological Setting}

The study area is located at the lower reaches of the river Lech and at the confluence of the Lech and Danube (Fig. 1). The Lech valley is characterised by several Pleistocene and Holocene terraces. The focus of this study are Holocene sediments which were deposited by the meandering Danube and the partly meandering, partly anabranching Lech river (Schielein, 2012).

\section{Fluvial environments in the study area}

Fluvial deposits in general can be classified according to their sedimentary environments. Reineck and Singh (1980) describe three groups of fluvial deposits: channel deposits, bank deposits and flood basin deposits. The latter two are often quite similar and can be subsumed as flood plain deposits. Within these fluvial sedimentary environments Reineck and Singh (1980) classify several types of sediments:

- channel deposits: channel lag, point bar, channel bar, channel fill

- floodplain deposits: natural levee, crevasse splay, flood basin, marsh.

In meandering rivers such as the Holocene Danube and in meandering channels of an anabranching river such as the Holocene Lech, deposition on point bars is the major sedimentation process. Sand layers are frequently deposited in swales and on the surface of point bars during bankfull discharge and are often buried under further layers of gravel, if a successive river bed sedimentation reaches the surface of the point bar. In river systems with

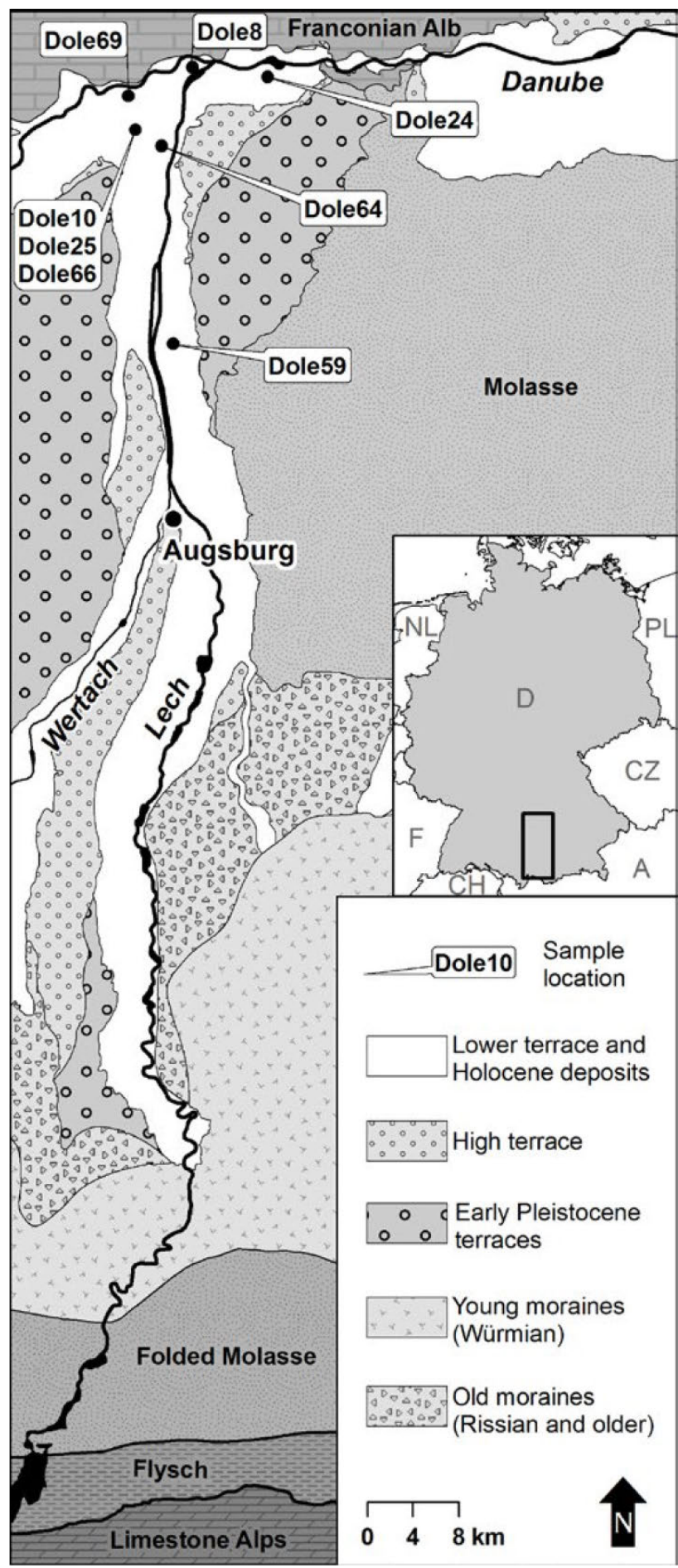

Fig. 1. Geological map of the study area and all sampling locations. 
braided or anabranching channels, gravel bars build up along the flow direction in channels.

Channel fill deposits of the Holocene Lech and Danube river form when channels have been abandoned due to avulsion of a stream channel or due to cut-off processes in meander loops. Moreover, channels can be cut into floodplain deposits and the underlying gravel deposits of a river terrace when branches of an anabraching river diverge from the main stream during flood events. If the river does not migrate in such a channel, it will be abandoned sooner or later. After abandonment all types of channels get filled with fine grained sediments, but in high energetic discharge during flood events, sands and even gravels can be deposited in a palaeo-channel.

During overbank flows, coarse sediments - mostly sand but also gravels - are deposited near the river channel on natural levees. Crevasse splays form in the floodplain behind levees when the latter are breached by an extreme flood event. Fine-grained suspended sediments are deposited with increasing distance from the river bed on the floodplain. These floodplain deposits are composed of horizontally bedded layers of fine sand, silt and clay, reaching several metres in thickness. In their lowest part, sand striped floodplain channel deposits sensu Schirmer (1995) can be identified, mainly in floodplains of meandering rivers. These deposits are accumulated during flood events on inactive point bars and represent the beginning of floodplain sedimentation. All fluvial environments in the study area are shown in a schematic illustration (Fig. 2).

\section{Independent chronostratigraphy of sampled deposits}

\section{Bar deposits}

The Lechauseen section was exposed in a gravel bar deposits from a Holocene Lech terrace ca. $25 \mathrm{~km}$ upstream of the Danube-Lech-confluence (Fig. 1). The gravels contain a sand lens at a depth of 1-1.5 m (Fig. 2a). Finds of rounded brick fragments in the gravel formation, which are present in fluvial accumulations solely since Roman times, allow assigning this terrace to the Subatlantic period ( 0-2500 a BP, Mangerud et al., 1974). From the sand lens, a sample for OSL dating (Dole59) and a charcoal sample for radiocarbon dating were taken. The charcoal was dated to $1565-1395 \mathrm{cal}$ BP (Schielein, 2012).

Another sample for OSL dating (Dole64) from a point bar deposit (Fig. 2a) was taken ca. $7 \mathrm{~km}$ upstream from the confluence in the Lech valley (Fig. 1). Here, a palaeomeander of the Lech river undercuts the subboreal (2500-5000 a BP, Mangerud et al., 1974) terrace and eroded parts of a Roman villa rustica at the outside bank. Archaeological data indicate the occupancy of the estate between the $1^{\text {st }}$ and the $4^{\text {th }}$ century $\operatorname{AD~(Czysz,~1990).~It~is~}$ likely that the villa rustica was abandoned because of the approaching Lech river. The point bar deposits at the sampling location, $300 \mathrm{~m}$ inbound from the inner bank of the palaeomeander, are expected to have been accumulated during Roman times, most likely around $1.6 \mathrm{ka}$ or slightly older, as the sampling location lies a few hundred meters inside of the meander bend and a point bar build up over some centuries can be assumed. (Schielein et al., 2011; Schielein, 2012).

\section{Channel fill deposits}

Samples Dole10, 25 and 66 were taken from channel fills in the same Lech terrace which is well exposed in the gravel pit of Eggelstetten (Fig. 1, Fig. 2b). The channels yielding samples 10 and 66 are cut ca. $1.5 \mathrm{~m}$ into the gravel body and are filled with loamy sands. Sample Dole25 was taken from a $2.3 \mathrm{~m}$ thick channel fill deposit consisting of well layered sand, silt, and clay, which was identified as floodplain deposit inside the channel. The correlation of the terrace level to the Subboreal was proposed by Schreiber (1985) and Roman streets and settlements on its surface confirm an age of at least $1.5 \mathrm{ka}$ (Schielein, 2012). In the Eggelstetten pit, at the base of the gravel body 2-4 m below the surface level, wood and plant remains yielded radiocarbon ages of $4968-4438 \mathrm{cal}$ BP (for details and further age evidence for the Subboreal deposition of this terrace see Schielein, 2012). The age of the channel fills should fall between the deposition of the terrace gravels and the roman settlement. Most likely, channel filling followed shortly after terrace aggradation.

\section{Floodplain deposits}

The Burgheim outcrop is situated at the inner bank of a palaeomeander in the Danube valley about $6 \mathrm{~km}$ downstream of the Lech-Danube confluence (Fig. 1). OSL sample Dole24 was taken from sand-striped floodplain channel deposits at a depth of $0.6 \mathrm{~m}$ below the surface level (Fig. 2c). The accumulation of the river terrace is assigned to the Subatlantic, based on its stratigraphical position, the weak soil formation and rounded brick fragments in the gravel body. ${ }^{14} \mathrm{C}$ age of $689-573 \mathrm{cal}$ $\mathrm{BP}$ was obtained from a horse jaw embedded in the gravel (Schielein, 2012).

Another sample (Dole69) was taken from floodplain deposits covering a Danube terrace $7 \mathrm{~km}$ upstream of the confluence (Fig. 1). The Reichertswert outcrop shows floodplain deposits formed of silty to clayey overbank fines in the higher part and a sand-striped floodplain channel deposit as lower part, from which the OSL-dated sands originate (Fig. 2c). The underlying gravel body contains rounded brick fragments and a pottery sherd at its top. The latter was archaeologically assigned to an age of about $1300 \mathrm{AD}$ by H. Losert (University of Bamberg, pers. comm.). The medieval terrace implies a younger age $(<0.7 \mathrm{ka})$ for the superimposed floodplain deposits.

One further samples (Dole8) was collected from a crevasse splay deposit lying on the recent Lech terrace about $1 \mathrm{~km}$ upstream from the confluence (Fig. 1). The crevasse splay stretches out from the natural levee of the 


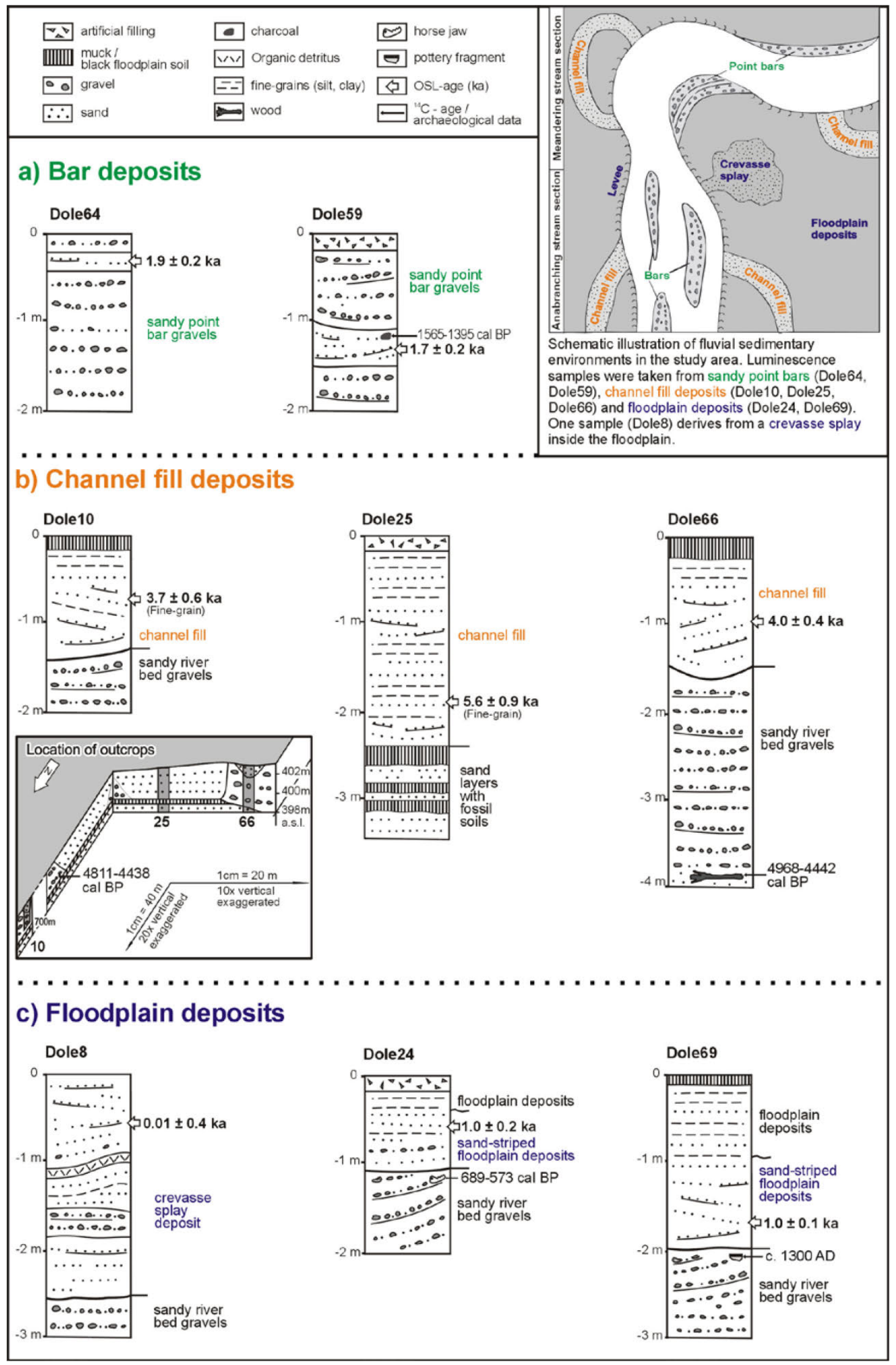

Fig. 2. Profiles of sampled deposits and their fluvial sedimentary environments (inset). Obtained luminescence ages are given in bold numbers. 
recent Lech river over an area of ca. $240 \times 400 \mathrm{~m}$. The outcrop consists of a layer of medium to coarse sands up to $1.5 \mathrm{~m}$ thick with bands of organic detritus, fine clastic sediments and gravels (Fig. 2c). The sands contain a high proportion of mica flakes, indicating that they are derived from nearby Tertiary Molasse sands building up the underlying stratum of the Quaternary river terraces and are exposed directly downriver from a Lech dam, situated only several tens of meters away from the outcrop. Therefore the sampled sands most likely experienced only a short transport and were deposited after the construction of the dam in the 1950s. Historical maps confirm that the outcrop is located in a $19^{\text {th }}$ century main stream of the anabranching Lech river (Schielein, 2010).

\section{METHODS}

A chronostratigraphy for the fluvial deposits in the study area was established using morphostratigraphic classifications, radiocarbon dating, archaeological data and historical maps. Radiocarbon dating of organic material was carried out by Beta Analytic Inc. (Miami) and Poznań Radiocarbon Laboratory. The ${ }^{14} \mathrm{C}$ ages ( $2 \sigma$ errors) were calibrated with OxCal software (Bronk-Ramsey, 1995) using the INTCAL 04 curve (Reimer et al., 2004). All ${ }^{14} \mathrm{C}$ ages are given as calibrated years BP (before 1950).

The luminescence samples derive from gravel or sand quarries. For the determination of the equivalent dose, the coarse grain fraction $(150-200 \mu \mathrm{m})$ of quartz was extracted from the bulk sediment by physical and chemical laboratory treatment (e.g. Lomax et al. 2007). The quartz grains were mounted on stainless steel discs, using a $2 \mathrm{~mm}$ mask, which approximates 100 to 150 grains per aliquot. For the two polymineral fine grain samples
(Dole10 and Dole25), the 4-11 $\mu \mathrm{m}$ fraction was enriched by settling using Stokes law. A suspension of the fine grain material $(40 \mathrm{mg})$ and acetone $(20 \mathrm{ml})$ was produced and $1 \mathrm{ml}$ of suspension each pipetted onto stainless steel discs, covering the entire $9 \mathrm{~mm}$ diameter disc. All preparation steps were undertaken under subdued red-light.

The standard measurements were carried out using the single-aliquot regenerative-dose (SAR) protocol of Murray and Wintle (2003). For stimulation, blue LEDs $\left(125^{\circ} \mathrm{C}\right.$ for $\left.40 \mathrm{~s}\right)$ were used and OSL emission was filtered through a U340 filter $(7.5 \mathrm{~mm})$. Signals were integrated over the first $0.6 \mathrm{~s}$, and with the subtraction of a background calculated using the last $10 \mathrm{~s}$ of the signal. Measurements were rejected if recycling ratios exceeded $10 \%$ from unity, recuperation exceeded $15 \%$ of natural signals and test dose errors exceeded $20 \%$. For the best bleached sample (Dole66), a preheat plateau test (Fig. 3a) was carried out to check the signal stability over a temperature range $\left(180\right.$ to $\left.280^{\circ} \mathrm{C}\right)$. Based on this test, the preheat and cutheat temperatures in most samples were set to $230(10 \mathrm{~s})$ and $200^{\circ} \mathrm{C}(0 \mathrm{~s})$, respectively. Two samples (Dole24 and Dole8) where dated in an earlier measurement cycle using different conditions, i.e. preheat and cutheat temperatures of $180(10 \mathrm{~s})$ and $160^{\circ} \mathrm{C}(0 \mathrm{~s})$, respectively. This is based on another preheat plateau test of sample Dole24 (Fig. 3b).

The applicability of the protocol was tested on three samples (Dole63, 64 and 69) through dose recovery tests. The natural signals were bleached in the luminescence reader using blue LEDs, and a known dose of 2 Gy was administered. Tests were performed on three $8 \mathrm{~mm}$ aliquots each and the same preheat-cutheat conditions as in the standard measurements were used. Dose recovery ratios of these three samples were 1.02, 1.00 and 0.99 (arithmetic mean), supporting the validity of the chosen
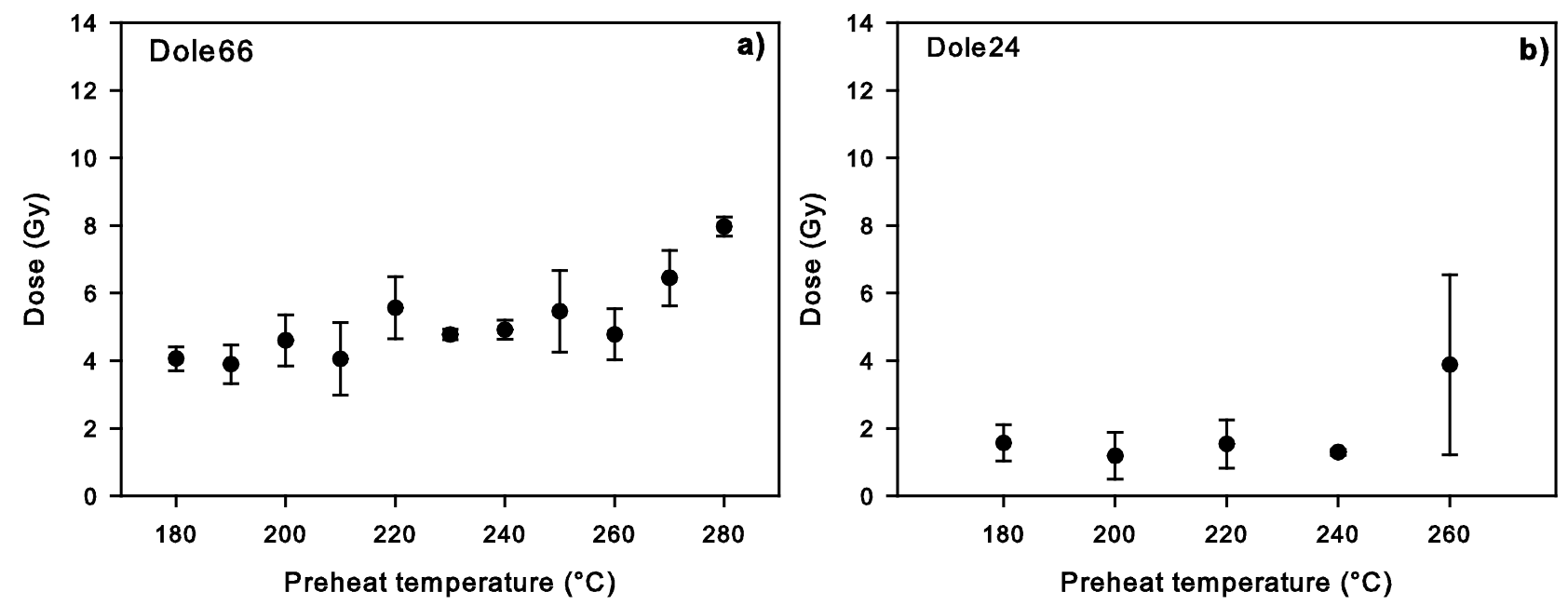

Fig. 3. Preheat plateau tests of sample a) Dole66 and b) Dole24. Each temperature was measured on three large (8 mm) aliquots and the cut-heat temperature was set to $200^{\circ} \mathrm{C}$ (for temperatures below $220^{\circ} \mathrm{C}$, to $20^{\circ} \mathrm{C}$ below the preheat temperature). $D_{e}$ values represent the arithmetic mean and the test was performed on naturally dosed samples. 
protocol. No feldspar contamination was present, which was tested at the end of each measurement sequence with an IR depletion test. Representative signal decay and dose response curves of the samples are shown in Fig. 4.

The two polymineral fine grain samples were measured using a SAR protocol (Wallinga et al., 2000; Blair et $a l ., 2005)$. Preheat temperatures were set to $190^{\circ} \mathrm{C}(10 \mathrm{~s})$, which was also based on a preheat plateau test. IRSL signals of polymineral fine grain samples are assumed to be dominated by the feldspar fraction. No fading tests were carried out on these two samples, thus a certain age underestimation might be expected. All measurements were conducted on Risø TL-DA-20 luminescence readers. Signals were detected through a LOT Oriel interference filter centered on $410 \mathrm{~nm}$.

As incomplete bleaching in fluvial environments is common due to attenuation of sunlight under water, such samples comprise grains that experienced different levels of signal resetting (Duller, 1994). The presence of incompletely bleached grains with various residual doses will cause a scatter and a positive skew of $D_{e}$ distributions. Many methods to detect and account for incomplete bleaching rely on analyses of these distributions (e.g. Olley et al., 1998; Lepper et al., 2000; Bailey and Arnold, 2006; Rodnight et al., 2006; Pietsch, 2009; Cunningham and Wallinga, 2012). In the current study, we apply the decision process of Bailey and Arnold (2006), to classify the degree of bleaching, and to decide on the statistical model for $\mathrm{D}_{\mathrm{e}}$ calculation.

Originally, the model of Bailey and Arnold (2006) was designed for single grain analyses, and care must be taken when transferring it to multiple grain analyses due to signal averaging effects (Arnold and Roberts, 2009). However, a range of studies showed that in insensitive samples, only very few grains contribute to the overall
OSL signal of a multiple grain disc and as a consequence, a multiple grain distribution can be very similar to that of single grains (e.g. Thrasher et al., 2009b; Cunningham and Wallinga, 2012). Calculated $\mathrm{D}_{\mathrm{e}}$ values are based on a minimum of 30 aliquots in case of coarse grain analysis and 5 aliquots for fine grain analysis. This is a relatively low number, compared to, e.g., the required $50 \mathrm{D}_{\mathrm{e}}$ values suggested by Rodnight (2008). In the current study, a higher number of accepted $D_{e}$ values could not be obtained due to insufficient reader capacity. The comparison with the independent ages shows that this low number of $D_{e}$ values might be sufficient; however, a higher number of accepted $D_{e}$ values would have been desirable.

This decision process of Bailey and Arnold (2006) uses the statistical parameters of overdispersion, weighted skewness and kurtosis for a characterisation of the $D_{e}$ distribution and based on these parameters, proposes the central age model (CAM, Galbraith et al., 1999), or minimum age models (MAM) for $\mathrm{D}_{\mathrm{e}}$ calculation. These minimum age models include the 3 and 4 parameter MAM-3 and MAM-4 (Galbraith et al., 1999) and the approach by Olley et al. (1998) to use only the mean of the lowest $\mathrm{x} \%$ of the $\mathrm{D}_{\mathrm{e}}$ values ( $\mathrm{L}-\mathrm{x} \%$ approach). We slightly simplified the decision process, by only using a MAM-3. Furthermore, we also calculated $D_{e}$ values using the Finite Mixture Model (FMM) (Galbraith and Green, 1990) in order to test it against the MAM and the independent age control. The FMM model is normally used for mixed dose populations (e.g. Roberts et al., 2000; Lomax et al. 2011), but can also be used for incompletely bleached samples, if the 'youngest' dose population is used for age calculation (Rodnight et al., 2006, Fiebig et al., 2009). While Rodnight et al. (2006) proposed to exclude the 'youngest' dose population where their proportion was $<10 \%$, this was not necessary for our samples; all
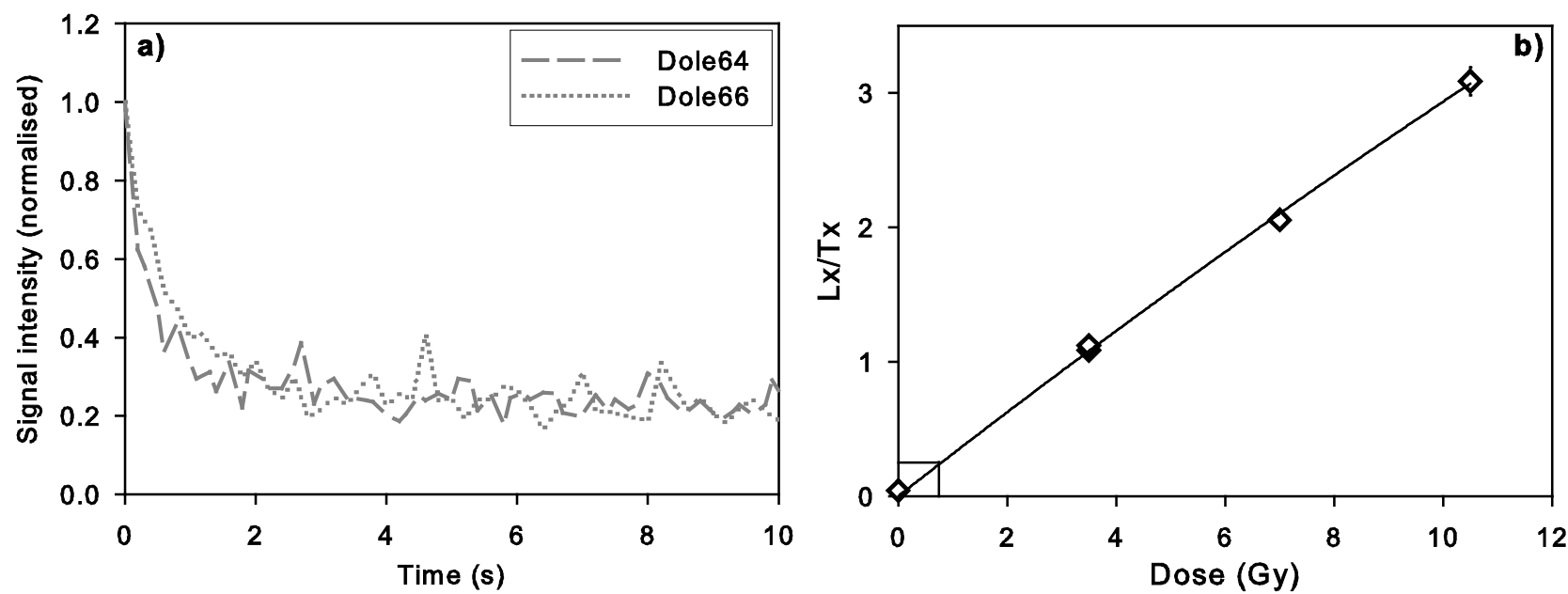

Fig. 4. a) Representative, normalised decay curves of samples Dole64 and Dole66. Signals were recorded using $2 \mathrm{~mm}$ aliquots, and the decay curves represent natural signals ( 1.5 Gy (Dole64) and $\sim 4.8 \mathrm{~Gy}$ (Dole66)). b) Representative dose response curve of sample Dole24. Signals were recorded using $2 \mathrm{~mm}$ aliquots, black lines represent the natural signal $\left(L_{n} / T_{n}\right)$ and equivalent dose of the respective aliquot. 
'youngest' dose populations had proportions of $>10 \%$. The MAM and the FMM require the input of a reference overdispersion value (the sigma value) which expresses variations caused by microdosimetry and differences in luminescence properties (e.g. recuperation). We used an estimated sigma-value of $20 \%$, as this seems to be a relatively common spread in well bleached samples analysed on single grain level (Arnold and Roberts, 2009). In case of the L-x\%-approach, we used a value of 5\% (L-5\%), as suggested in Olley et al. (1998).

U-, Th-, and K-concentrations were determined using laboratory gamma spectrometry on $\sim 800 \mathrm{~g}$ of sample material. None of the samples showed signs of radioactive disequilibria in the uranium decay chain. The radionuclide concentrations were converted to dose rates using conversion factors of Adamiec and Aitken (1998). Cosmic dose rates were calculated based on geographic position and sampling depth below surface (Prescott and Hutton, 1994). For the sandy samples, water contents of $10 \pm 7 \%$ were considered, whereas dose rates of silty samples were calculated with water contents of $17 \pm 7 \%$, which is an average of actual water contents. Radionuclide concentrations, dose rates and sample properties are summarised in Table 1.

\section{RESULTS}

Only one sample (Dole66) yielded a $\mathrm{D}_{\mathrm{e}}$ distribution which was not significantly skewed and we consider this sample well bleached (Fig. 5). For this sample, the decision process suggests the CAM. All other samples were significantly positively skewed, which led to the use of the minimum age models to calculate $\mathrm{D}_{\mathrm{e}}$ values (Fig. 5). Measurements of four samples resulted in the MAM or FMM as the mode of $D_{e}$ calculation. In three cases, FMM- and MAM-ages agreed with each other. In a fourth sample (Dole64), the MAM-age was significantly younger than the FMM-age, owing to two very precise $D_{e}$ values in the low dose range (Fig. 5).

One sample (Dole8) was severely incompletely bleached and resulted in the L-5\%-approach as mode of $\mathrm{D}_{\mathrm{e}}$ calculation. It needs to be considered that in our case, the $L-5 \% D_{e}$ is based on only two values, which is statistically unsound.

All $D_{e}$ values, relevant statistical parameters of $D_{e}$ distributions, resulting luminescence ages, and independent ages are summarised in Table 2.

\section{Bar deposits}

Both samples from bar deposits (Dole59 and 64) are incompletely bleached and the decision process of Bailey and Arnold (2006) resulted in the MAM. For Dole59, both the MAM and FMM resulted in agreeing ages of $1.7 \pm 0.2 \mathrm{ka}$, which is in accordance with the independent age control of $1565-1395 \mathrm{cal} \mathrm{BP}$.

The luminescence ages of Dole64 (MAM: $1.3 \pm 0.2 \mathrm{ka}$, FMM: $1.9 \pm 0.2 \mathrm{ka}$ ) are in agreement with the morphological position of the terrace between the Subboreal and recent Lech terraces and the archaeological data. As the latter designate an Roman age of the luminescence sample, most likely around $1.6 \mathrm{ka}$ or slightly older, the FMM-age is more appropriate. The low MAM-age is probably the result of very high precision $\mathrm{D}_{\mathrm{e}}$ values in the low dose range, and a too low number of accepted $D_{e}$ values.

\section{Channel fill deposits}

Samples Dole10, 25 and 66 were taken from channel fills, cut in the Subboreal Lech terrace and are expected to be slightly younger than c. $4.5 \mathrm{ka}$ cal BP. Sample Dole66 appears completely bleached when applying the

Table 1. Sample properties, radionuclide concentrations and dose rates. Dose rates include estimated water contents which represent averages of measured in-situ water contents.

\begin{tabular}{|c|c|c|c|c|c|c|c|c|}
\hline \multirow{2}{*}{ Sample } & \multirow{2}{*}{$\begin{array}{l}\text { Grain size } \\
\qquad(\mu \mathrm{m})\end{array}$} & \multirow{2}{*}{$\begin{array}{l}\text { Water } \\
\text { content } \\
(\%)\end{array}$} & \multirow{2}{*}{$\begin{array}{l}\text { Depth } \\
\text { (m) }\end{array}$} & \multicolumn{3}{|c|}{ Radionuclide concentrations } & \multirow{2}{*}{$\begin{array}{c}\text { Cosmic dose rate } \\
\text { (Gy/ka) }\end{array}$} & \multirow{2}{*}{$\begin{array}{l}\text { Total dose rate } \\
\text { (Gy/ka) }\end{array}$} \\
\hline & & & & K (\%) & $\mathrm{U}(\mathrm{ppm})$ & Th (ppm) & & \\
\hline Dole 59 & $150-200$ & $10 \pm 7$ & 1.2 & $0.46 \pm 0.01$ & $1.19 \pm 0.02$ & $1.54 \pm 0.05$ & $0.19 \pm 0.02$ & $0.93 \pm 0.07$ \\
\hline Dole 64 & $150-200$ & $10 \pm 7$ & 0.35 & $0.39 \pm 0.01$ & $0.83 \pm 0.02$ & $1.29 \pm 0.05$ & $0.22 \pm 0.03$ & $0.80 \pm 0.06$ \\
\hline Dole 66 & $150-200$ & $10 \pm 7$ & 1.2 & $0.53 \pm 0.01$ & $1.94 \pm 0.03$ & $2.51 \pm 0.08$ & $0.19 \pm 0.02$ & $1.21 \pm 0.09$ \\
\hline $\begin{array}{l}\text { Dole } 10 \\
\text { (polymin) }\end{array}$ & $4-11$ & $17 \pm 7$ & 1.05 & $0.47 \pm 0.01$ & $2.50 \pm 0.05$ & $2.75 \pm 0.09$ & $0.19 \pm 0.02$ & $1.82 \pm 0.25$ \\
\hline $\begin{array}{l}\text { Dole } 25 \\
\text { (polymin) }\end{array}$ & $4-11$ & $17 \pm 7$ & 1.9 & $0.40 \pm 0.01$ & $2.50 \pm 0.05$ & $2.29 \pm 0.09$ & $0.17 \pm 0.02$ & $1.69 \pm 0.24$ \\
\hline Dole 8 & $150-200$ & $10 \pm 7$ & 0.4 & $0.57 \pm 0.01$ & $0.93 \pm 0.03$ & $1.74 \pm 0.06$ & $0.21 \pm 0.03$ & $1.00 \pm 0.06$ \\
\hline Dole 69 & $150-200$ & $10 \pm 7$ & 1.8 & $0.88 \pm 0.01$ & $1.57 \pm 0.03$ & $3.88 \pm 0.12$ & $0.18 \pm 0.02$ & $1.50 \pm 0.12$ \\
\hline Dole 24 & $150-200$ & $10 \pm 7$ & 0.85 & $0.64 \pm 0.01$ & $0.93 \pm 0.03$ & $1.71 \pm 0.06$ & $0.20 \pm 0.03$ & $1.05 \pm 0.07$ \\
\hline
\end{tabular}


Table 2. Luminescence measurement details, independent ages, statistical parameters (OD = overdispersion after Galbraith et al. (1999); weighted skewness after Bailey and Arnold (2006); age model and resulting age according to Bailey and Arnold (2006) and alternative age model, which substitutes the Minimum Age Model (MAM) by the Finite Mixture Model (FMM); $n=$ number of aliquots used for $D_{e}$ calculation).

\begin{tabular}{|c|c|c|c|c|c|c|c|}
\hline Sample & $\begin{array}{l}\text { Fluvial envi- } \\
\text { ronment }\end{array}$ & $\begin{array}{c}\text { Over- } \\
\text { dispersion } \\
(\%)\end{array}$ & $\begin{array}{l}\text { Standardised } \\
\text { weighted skew } \\
\text { (significant?) }\end{array}$ & $\mathrm{n}$ & $\begin{array}{c}\text { De (Gy) } \\
\text { [Age model with } \\
\text { proportion of aliquots } \\
\text { used for } D_{\mathrm{e}^{-}} \\
\text {calculation (FMM)] }\end{array}$ & $\begin{array}{l}\text { Luminescence age [for } \\
\text { FMM ages also MAM } \\
\text { ages are mentioned] }\end{array}$ & $\begin{array}{l}\text { Independent age } \\
\qquad(\text { method })^{*}\end{array}$ \\
\hline Dole 59 & $\begin{array}{l}\text { Point bar } \\
\text { deposit }\end{array}$ & 39 & 2.6 (yes) & 30 & $\begin{array}{c}1.61 \pm 0.12 \\
{[\text { FMM, } 85 \%]}\end{array}$ & $\begin{array}{l}\text { FMM: } 1.7 \pm 0.2 \mathrm{ka} \\
\text { MAM: } 1.7 \pm 0.2 \mathrm{ka}\end{array}$ & $\begin{array}{c}1.4-1.6 \text { ka cal BP } \\
\left({ }^{14} \mathrm{C}\right)\end{array}$ \\
\hline Dole 64 & $\begin{array}{l}\text { Point bar } \\
\text { deposit }\end{array}$ & 52 & 3.6 (yes) & 42 & $\begin{array}{c}1.49 \pm 0.09 \\
{[\mathrm{FMM}, 76 \%]}\end{array}$ & $\begin{array}{l}\text { FMM: } 1.9 \pm 0.2 \mathrm{ka} \\
\text { MAM: } 1.3 \pm 0.2 \mathrm{ka}\end{array}$ & $\begin{array}{c}\text { Slightly older than } \\
1.6 \text { ka (archaeological } \\
\text { data) }\end{array}$ \\
\hline Dole 66 & $\begin{array}{l}\text { Sandy channel } \\
\text { fill }\end{array}$ & 25 & 0.8 (no) & 32 & $\begin{array}{l}4.81 \pm 0.30 \\
{[\mathrm{CAM}]}\end{array}$ & CAM: $4.0 \pm 0.4 \mathrm{ka}$ & $\begin{array}{l}\text { Slightly younger than } \\
\sim 4.5 \text { ka cal BP }\left({ }^{14} \mathrm{C}\right)\end{array}$ \\
\hline $\begin{array}{l}\text { Dole } 10 \\
\text { (polymin) }\end{array}$ & $\begin{array}{l}\text { Silty channel } \\
\text { fill }\end{array}$ & 3 & 0.3 (no) & 5 & $\begin{array}{c}6.69 \pm 0.36 \\
{[\mathrm{CAM}]}\end{array}$ & CAM: $3.7 \pm 0.6 \mathrm{ka}$ & $\begin{array}{l}\text { Slightly younger than } \\
\sim 4.5 \text { ka cal BP }\left({ }^{14} \mathrm{C}\right)\end{array}$ \\
\hline $\begin{array}{l}\text { Dole } 25 \\
\text { (polymin) }\end{array}$ & $\begin{array}{l}\text { Silty channel } \\
\text { fill }\end{array}$ & 0 & 0.1 (no) & 5 & $\begin{array}{l}9.45 \pm 0.59 \\
{[\mathrm{CAM}]}\end{array}$ & CAM: $5.6 \pm 0.9 \mathrm{ka}$ & $\begin{array}{l}\text { Slightly younger than } \\
\sim 4.5 \text { ka cal BP }\left({ }^{14} \mathrm{C}\right)\end{array}$ \\
\hline Dole 8 & Crevasse splay & 116 & 7.5 (yes) & 38 & $\begin{array}{c}0.01 \pm 0.35 \\
{[L-5 \%]}\end{array}$ & L-5\%: $0.01 \pm 0.4$ ka & $\begin{array}{l}\text { Younger than } 50 \\
\text { years }\end{array}$ \\
\hline Dole 69 & $\begin{array}{l}\text { Sand-striped } \\
\text { flood plain }\end{array}$ & 59 & 4.0 (yes) & 38 & $\begin{array}{c}1.43 \pm 0.10 \\
{[\text { FMM, } 65 \%]}\end{array}$ & $\begin{array}{l}\text { FMM: } 1.0 \pm 0.1 \mathrm{ka} \\
\text { MAM: } 0.9 \pm 0.1 \mathrm{ka}\end{array}$ & $\begin{array}{l}\text { Slightly younger than } \\
0.71 \text { ka (archaeologi- } \\
\text { cal data) }\end{array}$ \\
\hline Dole 24 & $\begin{array}{l}\text { Sand-striped } \\
\text { flood plain }\end{array}$ & 65 & 2.5 (yes) & 42 & $\begin{array}{c}1.06 \pm 0.13 \\
{[\text { FMM, 36\%] }}\end{array}$ & $\begin{array}{l}\text { FMM : } 1.0 \pm 0.2 \mathrm{ka} \\
\text { MAM: } 0.9 \pm 0.1 \mathrm{ka}\end{array}$ & $\begin{array}{l}\text { Slightly younger than } \\
0.69-0.57 \mathrm{ka} \text { cal BP } \\
\left({ }^{14} \mathrm{C}\right)\end{array}$ \\
\hline
\end{tabular}

${ }^{*}$ For details concerning ${ }^{14} \mathrm{C}$ dating see Table 3.

Table 3. Radiocarbon dating details. The ${ }^{14} \mathrm{C}$ ages (2 $\sigma$ errors) were calibrated with OxCal software (Bronk-Ramsey, 1995) using the INTCAL 04 curve (Reimer et al., 2004).

\begin{tabular}{llcc}
\hline $\begin{array}{l}\text { Laboratory } \\
\text { code }\end{array}$ & Material & $\begin{array}{c}{ }^{14} \mathrm{C} \text { age } \\
\left({ }^{14} \mathrm{C} \text { BP) }\right.\end{array}$ & $\begin{array}{c}\text { calibration results, } \\
\mathbf{9 5 . 4 \%} \text { conf. } \\
\text { intervals (cal BP) }\end{array}$ \\
\hline Poz-32651 & horse jaw & $715 \pm 30$ & $690-570$ \\
Beta-245225 & wood & $4130 \pm 60$ & $4840-4440$ \\
Beta-256322 & wood & $4290 \pm 50$ & $4970-4820$ \\
Beta-262203 & plant remains & $4080 \pm 40$ & $4810-4440$ \\
Beta-265925 & charcoal & $1600 \pm 40$ & $1570-1400$ \\
\hline
\end{tabular}

criteria of Bailey and Arnold (2006), resulting in the $\mathrm{CAM}$ as the mode of mean $\mathrm{D}_{\mathrm{e}}$ calculation. The model gives an age of $4.1 \pm 0.4 \mathrm{ka}$ and agrees with the independent age estimates. Samples Dole10 and 25 were dated using the feldspar-dominated signal of the polymineral fine grain fraction, as not enough sand sized material was available for coarse grain quartz dating. The technique does not allow analysis of $\mathrm{D}_{\mathrm{e}}$ distributions to detect incomplete bleaching, as $\mathrm{D}_{\mathrm{e}}$ variations on a grain to grain scale are masked by the large aliquot size. Therefore, the
CAM was used for the $\mathrm{D}_{\mathrm{e}}$ mean calculation. The IRSL age of $3.7 \pm 0.6 \mathrm{ka}$ of sample Dole10 is in agreement with the ${ }^{14} \mathrm{C}$ age constraint and with the OSL-age of sample Dole66. Dole25 yields an IRSL age of 5.6 \pm 0.9 ka which overestimates the age of the terrace.

\section{Floodplain deposits}

Dole69 and 24 are derived from sand-striped floodplain channel deposits and overlie a terrace with an age of $\sim 0.7 \mathrm{ka}$ which represents the maximum age of the luminescence samples. It can be assumed that the deposition of these floodplain sediments took place shortly after terrace aggradation. Both samples are incompletely bleached and result in using the MAM or the FMMmodel as mode of $D_{e}$ calculation. The resulting quartz ages of $0.9 \pm 0.1$ (Dole69) and $0.9 \pm 0.2 \mathrm{ka}$ (Dole24) coincide with the independent ages on a $2 \sigma$ error level. One further sample (Dole8) from a crevasse splay should have yielded a modern age of less than 50 years, most likely even a recent age. The sample was severely unbleached, containing doses corresponding to ages up to $90 \mathrm{ka}$. The decision process suggests a L-5\% approach, resulting in an age of $0.01 \pm 0.35 \mathrm{ka}$. This age agrees with the inde- 


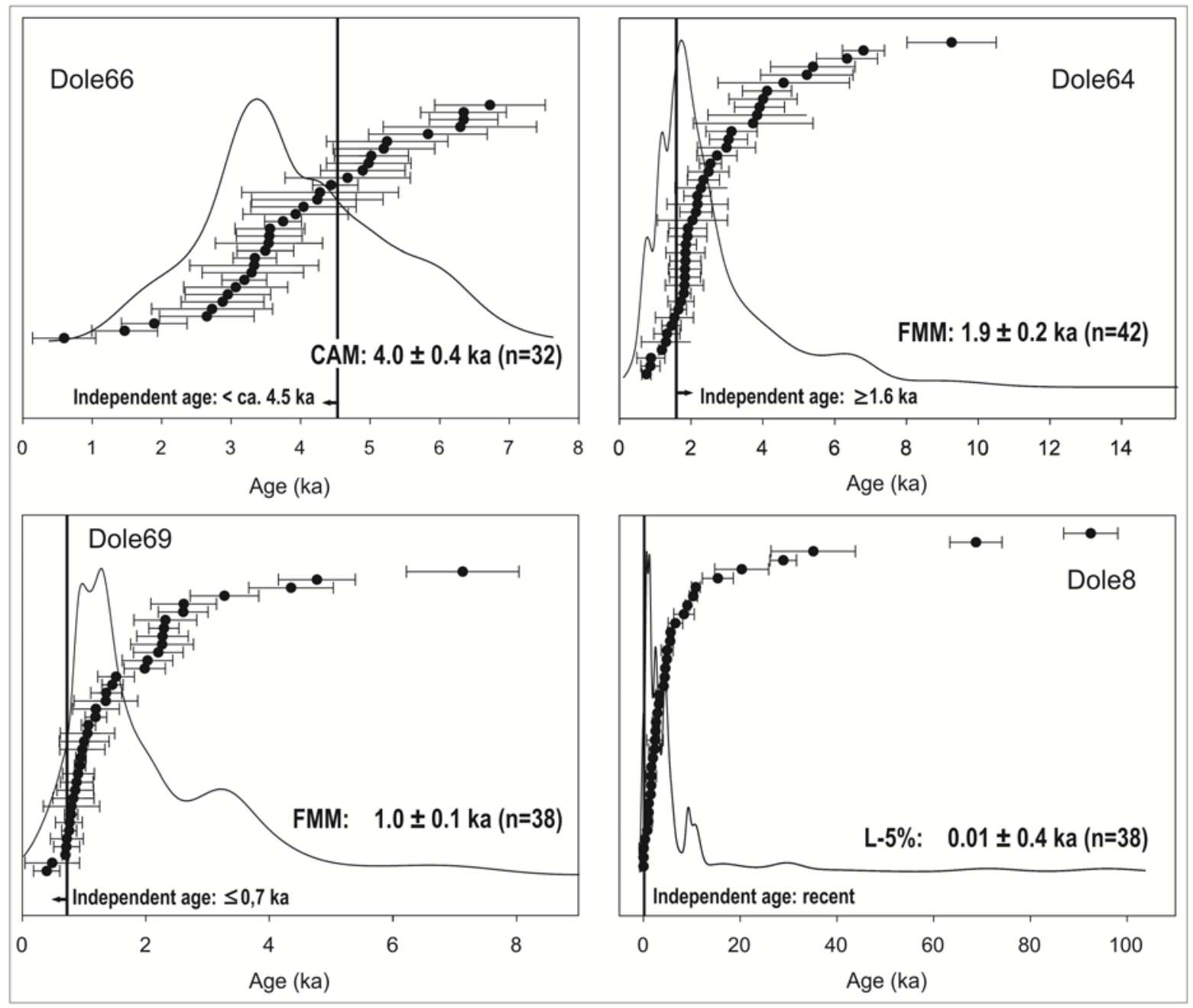

Fig. 5. Frequency distributions and probability density functions of luminescence ages for one channel fill (Dole66), one point bar (Dole64), one floodplain (Dole69) and the crevasse splay (Dole8) deposit. Each individual age (circle with error range) was calculated by dividing the $D_{e}$ value of one aliquot by the total dose rate. The bars and arrows indicate the independent age control.

pendent age control, but exhibits a very large uncertainty. As mentioned before, this age is based on only two $D_{e}$ values and thus needs to be considered as unreliable.

\section{DISCUSSION}

The OSL measurements of Holocene fluvial deposits from different sedimentary environments demonstrated varying degrees of bleaching. Most of the analysed fluvial samples are incompletely bleached but contain a high enough proportion of well bleached grains to yield accurate ages when minimum age models are used. Most likely the different degree of bleaching is a function of transport distance and mechanism, the previously accumulated dose and/or the duration of light exposure during sediment deposition.
A sandy channel fill deposit appeared as best bleached, yielding CAM ages in agreement with independent age control. Successful OSL dating of coarse grained Holocene channel fills was reported by Wallinga et al. (2001) for the Rhine-Meuse-Delta and by Fiebig et al. (2009) from the Austrian Danube and the Ebro. The bar deposits dated in our study were incompletely bleached, but yielded a high percentage of bleached grains, resulting in MAM and FMM ages agreeing with the independent ages. Porat et al. (2001) detected substantial residual doses of bar and active channels deposits in southern Israel, especially when the sediments experienced an adequate transport distance. The two sand striped floodplain deposits also yielded accurate MAM and FMM-ages within errors. A further sample from a crevasse splay, which obviously experienced only a very short transport and had accumulated a very high dose 
prior to this transport, was severely incompletely bleached, and resulted in a L-5\% age with a very large uncertainty.

The degree of bleaching apparently depends on the transport distance and the degree of light exposure in different sub-environments. During high energetic discharge in active (bars) and abandoned channels (channel fills) the potential of bleaching the deposits is relatively high, as the water body does not contain much suspended sediment. In contrast, floodplain sediments typically show a low bleaching potential, due to the high amount of suspended fine-grained material in the water body and the resulting low amount of light exposure during transport.

The well bleached nature of the sandy channel fill sample (Dole66) in comparison with the age overestimation of a fine grained sample (Dole25) from the same environment may be indicative of faster bleaching of the quartz fraction compared to the feldspar fraction, as suggested by Godfrey-Smith et al. (1988). Another explanation is the larger degree of averaging on the large fine grain discs which contain many thousands of luminescent grains. In any case, fine grain dating should be avoided when dating fluvial samples, as this mineral fraction does not offer the required resolution for detecting incomplete bleaching. An alternative is to consider fine grain luminescence ages of fluvial samples only as maximum estimates. However, the sample Dole25 was taken from a channel filled with finer grains and is likely to be less bleached due to lower light exposure during floodplain sedimentation. In contrast, sample Dole10 is derived from a channel filled with loamy sands which were deposited under high energetic discharge in the channel and therefore are better bleached.

The decision process of Bailey and Arnold (2006) yields ages in agreement with independent age control in all cases where the quartz coarse grain fraction was measured. Hence, the decision process, originally designed for single grains of quartz can be applicable to multiple grain analyses under the premise that only a small percentage of luminescent grains are present in the samples. This finding supports the previous work of Thrasher et al. (2009b). Hence, for our samples, the decision process proved to be a powerful tool to detect incomplete bleaching and to decide on the mode of $\mathrm{D}_{\mathrm{e}}$ calculation.

\section{CONCLUSION}

The study has shown that luminescence dating of young fluvial deposits can yield age estimates which are in agreement with independent age control. Measuring small aliquots of quartz in combination with the decision process of Bailey and Arnold (2006) appears the most suitable approach in the investigated environment, but care should be taken in the choice of fluvial environments. Fine-grained material which can only be dated using large aliquots should be avoided, as well as samples with a short transport distance and high previously acquired doses, such as re-deposited Tertiary Molasse. For our study area, albeit tested on a limited number of samples, bar deposits and sandy channel fills are likely to be better bleached than floodplain deposits. For future luminescence dating of fluvial deposits, we suggest a detailed survey of sedimentological properties of the samples including the identification of fluvial environments as well as the comparison with independent age control derived from other numerical dating methods and the morphostratigraphic situation.

\section{REFERENCES}

Adamiec G and Aitken M, 1998. Dose-rate conversion factors: update. Ancient TL 16: 37-50.

Arnold LJ and Roberts RG, 2009. Stochastic modelling of multi-grain equivalent dose $\left(D_{\mathrm{e}}\right)$ distributions: Implications for OSL dating of sediment mixtures. Quaternary Geochronology 4(3): 204-230, DOI 10.1016/j.quageo.2008.12.001.

Bailey RM and Arnold LJ, 2006. Statistical modelling of single grain quartz $\mathrm{D}_{\mathrm{e}}$ distributions and an assessment of procedures for estimating burial dose. Quaternary Science Reviews 25(19-20): 24752502, DOI 10.1016/j.quascirev.2005.09.012.

Blair MW, Yukihara EG and McKeever SWS, 2005. Experiences with single aliquot OSL procedures using coarse-grain feldspars. Radiation Measurements 39(4): 361-374, DOI 10.1016/j.radmeas.2004.05.008.

Bronk Ramsey C, 1995. Radiocarbon calibration and analysis of stratigraphy: The OxCal program. Radiocarbon 37(2): 425-430.

Cunningham AC and Wallinga J, 2012. Realizing the potential of fluvial archives using robust OSL chronologies. Quaternary Geochronology 12: 98-106, DOI 10.1016/j.quageo.2012.05.007.

Czysz W, 1990. Ausgrabungen in einem römischen Gutshof bei Oberndorf a. Lech (Excavations in a Roman estate near Oberndorf a. Lech). Das archäologische Jahr in Bayern 1989, 133-140 (in German).

Duller GAT, 1994. Luminescence dating of poorly bleached sediments from Scotland. Quaternary Science Reviews 13(5-7): 521-524, DOI 10.1016/0277-3791(94)90070-1.

Fiebig M, Preusser F, Steffen D, Thamo-Bozso E, Grabner M, Lair GJ and Gerzabek MH, 2009. Luminescence Dating of Historical Fluvial Deposits from the Danube and Ebro. Geoarchaeology 24(2), 224-241, DOI 10.1002/gea.20264.

Fuchs $\mathrm{M}$ and Owen LA, 2008. Luminescence dating of glacial and associated sediments: review, recommendations and future directions. Boreas 37(4): 636-659, DOI 10.1111/j.15023885.2008.00052.x.

Galbraith RF and Green PF, 1990. Estimating the component ages in a finite mixture. International Journal of Radiation Applications and Instrumentation. Part D. Nuclear Tracks and Radiation Measurements 17(3): 197-206, DOI 10.1016/1359-0189(90)90035-V.

Galbraith RF, Roberts RG, Laslett GM, Yoshida H and Olley JM, 1999. Optical dating of single and multiple grains of quartz from Jinmium rock shelter, northern Australia: Part I, experimental design and statistical models. Archaeometry 41(2): 339-364, DOI 10.1111/j.1475-4754.1999.tb00987.x.

Godfrey-Smith DI, Huntley DJ and Chen WH, 1988. Optical Dating studies of quartz and feldspar sediment extracts. Quaternary Science Reviews 7(3-4): 373-380, DOI 10.1016/0277-3791(88)900327.

Jain M, Murray AS and Botter-Jensen L, 2004. Optically stimulated luminescence dating: How significant is incomplete light exposure in fluvial environments? Quaternaire 15: 143-157.

Klasen N, Fiebig M, Preusser F and Radtke U, 2006. Luminescence properties of glaciofluvial sediments from the Bavarian Alpine 
Foreland. Radiation Measurements 41(7-8): 866-870, DOI 10.1016/j.radmeas.2006.04.014

Lepper K, Agersnap-Larsen N and McKeever SWS, 2000. Equivalent dose distribution analysis of Holocene eolian and fluvial quartz sands from central Oklahoma. Radiation Measurements 32(5-6): 603-608, DOI 10.1016/S1350-4487(00)00093-7.

Lomax J, Hilgers A, Twidale CR, Bourne JA and Radtke U, 2007. Treatment of broad equivalent dose distributions in OSL dating of dune sands from the western Murray Basin, South Australia. Quaternary Geochronology 2(1-4): 51-56, DOI 10.1016/j.quageo.2006.05.015.

Lomax J, Hilgers A, Radtke U, 2011. Palaeoenvironmental change recorded in the palaeodunefields of the western Murray Basin, South Australia - new data from single grain OSL-dating. Quaternary Science Reviews 30(5-6): 723-736, DOI 10.1016/j.quascirev.2010.12.015.

Lukas S, Spencer JQC, Robinson RAJ and Benn DI, 2007. Problems associated with luminescence dating of Late Quaternary glacial sediments in the NW Scottish Highlands. Quaternary Geochronology 2(1-4): 243-248, DOI 10.1016/j.quageo.2006.04.007.

Mangerud J, Andersen ST, Berglund BE and Donner JJ, 1974. Quaternary stratigraphy of Norden, a proposal for terminology and classification. Boreas 3(3): 109-128, DOI 10.1111/j.15023885.1974.tb00669.x.

Murray AS and Wintle AG, 2003. The single aliquot regenerative dose protocol: potential for improvements in reliability. Radiation Measurements 37(4-5): 377-381, DOI 10.1016/S13504487(03)00053-2.

Olley J, Caitcheon G and Murray AS, 1998. The distribution of apparent dose as determined by optically stimulated luminescence in small aliquots of fluvial quartz: implications for dating young sediments. Quaternary Science Reviews 17(11): 1033-1040, DOI 10.1016/S0277-3791(97)00090-5.

Pietsch TJ, 2009. Optically stimulated luminescence dating of young ( $<500$ years old) sediments: Testing estimates of burial dose. Quaternary Geochronology 4(5): 406-422, $\quad$ DOI 10.1016/j.quageo.2009.05.013.

Pietsch TJ, Olley JM and Nanson GC, 2008. Fluvial transport as a natural luminescence sensitiser of quartz. Quaternary Geochronology 3(4): 365-376, DOI 10.1016/j.quageo.2007.12.005.

Porat N, Zilberman E, Amit R and Enzel Y, 2001. Residual ages of modern sediments in an hyperarid region, Israel. Quaternary $S c i$ ence Reviews 20(5-9): 795-798, DOI 10.1016/S02773791(00)00021-4.

Prescott JR and Hutton JT, 1994. Cosmic ray contributions to dose rates for luminescence and ESR dating: large depth and long-term time variations. Radiation Measurements 23(2-3): 497-500, DOI 10.1016/1350-4487(94)90086-8.

Preusser F, Ramseyer K and Schlüchter C, 2006. Characterisation of low OSL intensity quartz from the New Zealand Alps. Radiation Measurements $\quad 41(7-8)$ 10.1016/j.radmeas.2006.04.019.

Reimer PJ, Baillie MGL, Bard E, Bayliss A, Beck JW, Bertrand C, Blackwell PG, Buck CE, Burr G, Cutler KB, Damon PE, Edwards RL, Fairbanks RG, Friedrich M, Guilderson TP, Hughen KA, Kromer B, McCormac FG, Manning S, Bronk Ramsey C, Reimer RW, Remmele S, Southon JR, Stuiver M, Talamo S, Taylor FW, van der Plicht J and Weyhenmeyer CE, 2004. IntCal04 Terrestrial radiocarbon age calibration, $0-26$ cal kyr BP. Radiocarbon 46: 1029-1058.
Reineck H-E and Singh IB, 1980. Depositional sedimentary environments. Springer, Berlin. 549 pp.

Rhodes EJ and Pownall L, 1994. Zeroing of the OSL signal in quartz from young glaciofluvial sediments. Radiation Measurements 23(2-3): 581-585, DOI 10.1016/1350-4487(94)90103-1.

Rittenour TM, 2008. Luminescence dating of fluvial deposits: applications to geomorphic, palaeoseismic and archaeological research. Boreas 37(4): 613-635, DOI 10.1111/j.1502-3885.2008.00056.x.

Roberts RG, Galbraith RF, Yoshida H, Laslett GM and Olley JM, 2000. Distinguishing dose populations in sediment mixtures: a test of single-grain optical dating procedures using mixtures of laboratory-dosed quartz. Radiation Measurements 32(5-6): 459-465, DOI 10.1016/S1350-4487(00)00104-9.

Rodnight H, Duller GAT, Wintle AG and Tooth, S, 2006. Assessing the reproducibility and accuracy of optical dating of fluvial deposits. Quaternary Geochronology 1(2): 109-120, DOI 10.1016/j.quageo.2006.05.017.

Rodnight H, 2008. How many equivalent dose values are needed to obtain a reproducible distribution? Ancient TL 28(1): 3-9.

Schielein P, 2010. Neuzeitliche Flusslaufverlagerungen des Lechs und der Donau im Lechmündungsgebiet - qualitative und quantitative Analysen historischer Karten (Modern river relocation of the Lech and Danube rivers at their confluence - qualitative and quantitative analysis of historical maps). Bamberger Geographische Schriften 24, 215-241 (in German).

Schielein P, Schellmann G and Lomax J, 2011. Stratigraphy of Late Quaternary fluvial terraces at the confluence of the Lech and Danube valleys. Eiszeitalter und Gegenwart - Quaternary Science Journal 60(4): 414-424.

Schielein P, 2012. Jungquartäre Flussgeschichte des Lechs unterhalb von Augsburg und der angrenzenden Donau (Late Quaternary fluvial history of the Lech river downstream of Augsburg and of the adjacent Danube). Bamberger Geographische Schriften - Sonderfolge $9,150 \mathrm{p}$ (in German).

Schirmer W, 1995. Valley bottoms in the Late Quaternary. Zeitschrift für Geomorphologie Supplement 100: 27-51.

Schreiber U, 1985. Das Lechtal zwischen Schongau und Rain im Hoch-, Spät- und Postglazial (The Lech valley between Schongau und Rain in the Pleni-, Late- and Postglacial). Geologisches Institut der Universität zu Köln, Sonderveröffentlichungen 58 (in German).

Steffen D, Preusser F and Schlunegger F, 2009. OSL quartz age underestimation due to unstable signal components. Quaternary Geochronology 4(5): 353-362, DOI 10.1016/j.quageo.2009.05.015.

Thrasher IM, Mauz B, Chiverrell RC and Lang A, 2009a. Luminescence dating of glaciofluvial deposits. A review. Earth-Science Reviews 97(1-4): 133-146, DOI 10.1016/j.earscirev.2009.09.001.

Thrasher IM, Mauz B, Chiverrell RC, Lang A and Thomas GSP, 2009b. Testing an approach to OSL dating of Late Devensian glaciofluvial sediments of the British Isles. Journal of Quaternary Science 24(7): 785-801, DOI 10.1002/jqs.1253.

Wallinga J, Murray AS and Wintle AG, 2000. The single-aliquot regenerative-dose (SAR) protocol applied to coarse-grain feldspar. $R a-$ diation Measurements 32(5-6): 529-533, DOI 10.1016/S13504487(00)00091-3.

Wallinga J, Murray AS, Duller GAT and Törnqvist TE, 2001. Testing optically stimulated luminescence dating of sand-sized quartz and feldspar from fluvial deposits. Earth and Planetary Science Letters 193(3-4): 617-630, DOI 10.1016/S0012-821X(01)00526-X. 